\title{
REGIONAL DEVELOPMENT IN ŞANLIURFA PROVINCE : KEY SECTOR ANALYIS
}

\author{
Asist.Prof.Dr. Meneviş Uzbay Pirili, Ege University, Faculty of Economics and \\ Administrative Siences, Department of Economics, menevis.uzbay@ege.edu.tr \\ Prof.Dr. R.Funda Barbaros, Ege University, Faculty of Economics and \\ Administrative Siences, Department of Economics, funda.barbaros@ege.edu.tr
}

\begin{abstract}
The challenges facing Şanlıurfa are not unique, they are the same challenges found in rural areas all around the world. Agriculture is still the most important sector in Şanlıurfa, but it is generating fewer and fewer jobs. New approaches used in regional development shift from a focus on individual sectors (such as agriculture policy) to one based on a comprehensive multisectoral approach in which agriculture is conceived as one component sector of a comprehensive regional development policy. Within this framework, there are two major aims of this study. The first aim is to identify the high point sectors (key industries) by using LQ analysis in Şanlıurfa province and 11 districts. On the other hand the economy of Şanlıurfa, endowed with very rich arable land resources and irrigation facilities, thanks to GAP-( SouthEastern Anatolian Project), has a high potential in organic-agriculture. Accordingly the second aim of this paper is to analyze the development potentials of "clusters of agro-industries based on organic agriculture products" in the region. The findings of the analysis reveal that the key sectors identified in industry and services (food and textiles industries and retail and wholesale of food stuff) provide inputs from the main agricultural products in the region. On the other hand considering the availability of land and other facilities for organic agricultural products the findings of the study strongly supports development of "clusters of organic agro industries" in Şanlıurfa Region.
\end{abstract}

Keywords: Key sectors, Organic agriculture clusters, GAP, Şanlı Urfa, Regional Development 


\section{INTRODUCTION}

The challenges facing Şanlıurfa regarding its economic development is not unique, they are the same challenges found in rural areas all around the world. Although agriculture is still the most important economic sector in Şanlıurfa (with $42 \%$ of the population living in rural areas and the agriculture's share in regions GDP amounts to $43 \%$ ) it is producing fewer and fewer jobs. The region suffers from the highest out migration rates all over Turkey. Declining employment opportunities in agriculture, inadequate access to education and leisure facilities and declining job opportunities in the public sector employment due to recent climate of fiscal restraint are among the main reasons of high rates of out migration.

New regional development approaches and policies are responding these challenges in many different ways, and successful policies have some common characteristics. First, regional policy in rural areas shifts from a focus on individual sectors (such as farm policy) to one based on a comprehensive multisectoral approach in which agriculture is conceived as one component sector of a comprehensive regional development policy. Second the coordination of policies at the regional level often means forming partnership amoung various public departments, knowledge producing institutes as well as private and non profit sectors. Third, regarding the identification of the sectors that have high growth potentials in the region and also the relevant policies to be implemented, "cluster" approaches have proved to be successful.

Within this framework, there are two major aims of this study. The first aim is to identify the high point sectors (key industries) by using LQ analysis in Şanlıurfa province and 11 districts. The analysis encompasses all sectors of industry and services thus excluding agriculture. One important feature of Şanlıurfa is that the region has high potentials for the improvement of organic agriculture sector. The organic cluster map study carrried out by GAP- GIDEMEastern Anatolian Project Entrepreneur Support Centers - reveals that there is a strong potential for the improvement of organic agriculture, however the network relations between the possible actors of an organic cluster are still weak. Accordingly the second aim of this paper is to analyze the development potentials of "clusters of agro-industries based on organic agriculture products" in the region.

\section{SOCIO-ECONOMIC PROFILE OF SANLI URFA PROVINCE}

Amoung the 26 NUTS 2 regions defined by State Planning Organization in the the framework of regional development policies, Şanlıurfa is grouped together with Diyarbakır under the code TRC2. At NUTS 3 level its code is defined as TRC21. Map 1 shows 9 Provinces of the south eastern Anatolia. 


\section{Map 1: Şanlı Urfa in South East Anatolia Region}

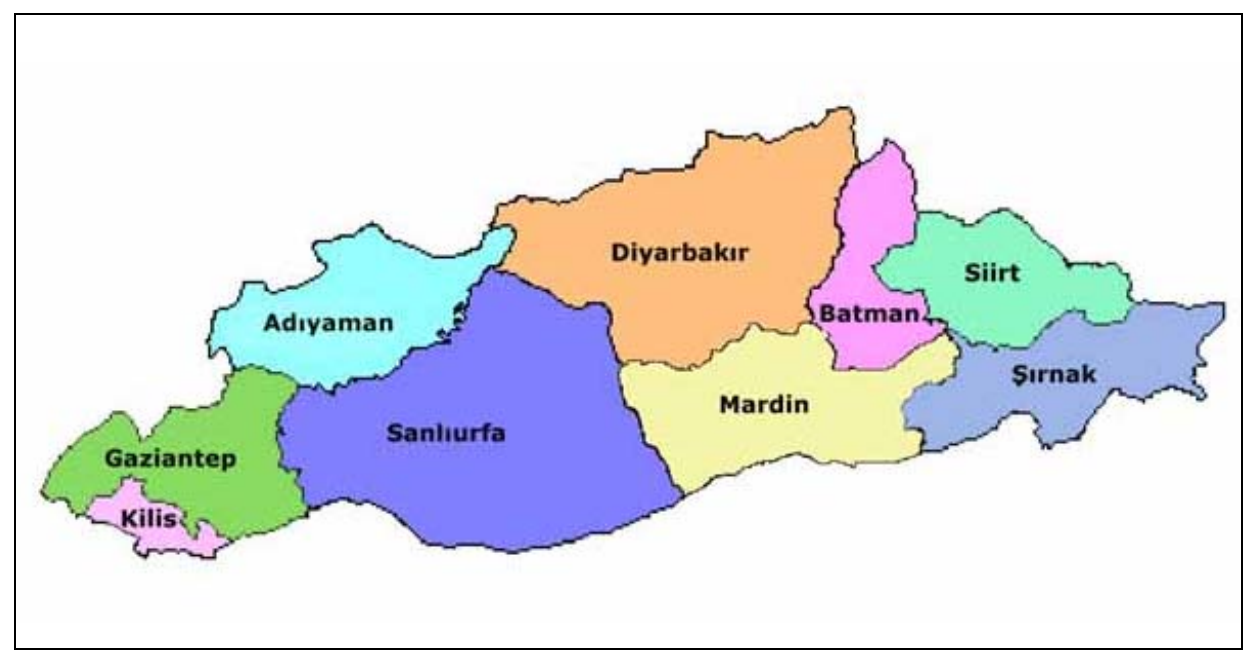

The surface area of Sanlıurfa located in Southeastern Anatolia Region of Turkey is $19.020 \mathrm{~km}^{2}$ and this constitutes $3 \%$ of the total surface area of Turkey (Bulu and Eraslan, 2004). Sanlıurfa is the Center City of GAP project. Sanliurfa is surrounded by Gaziantep in the west, Adıyaman in the northwest, Diyarbakır in the northeast, Mardin in the east, and Syria in the south. There are 11 districs including the central district. These are Akçakale, Birecik, Bozova, Ceylanpınar, Halfeti, Harran, Hilvan, Suruç, Siverek and Viranşehir.

\subsection{Demographic Structure}

As it may be seen in Table 1, total population including the central province and districts is $1,443,42$ according to 2000 census. Population growth rate is 30.9 $(\%)$, far above the average of Turkey $(14.9 \%)$. On the other hand the average size of a household in the province is higher than 4.5, the average of Turkey. It is 6.87. Namely, approximately 7 persons live in a house. When the distribution according to age is considered, the province has a quiet young population. 0-4 age group has the biggest share within population. It is estimated that the population of Sanlıurfa will reach 1.9 million in 2010 through this rapidly growing population.

The economy of Sanliurfa is based on agriculture. As it may be seen in Table 1 nearly $42 \%$ of the population live in rural area. Urbanization rate decreases down to $30 \%$ in the districts except the central district. However with $58 \%$ urbanization rate, the province is below the average of Turkey which is $\% 65$. 
Table 1:Demographic Indicators - 2000

\begin{tabular}{|l|r|r|r|r|r|r|}
\hline Codes & \multicolumn{1}{|c|}{$\begin{array}{c}\text { Total } \\
\text { Population }\end{array}$} & $\begin{array}{c}\text { Urban } \\
\text { populati } \\
\text { on } \\
\text { growth } \\
\text { rate \% }\end{array}$ & $\begin{array}{c}\text { Population } \\
\text { growth } \\
\text { rate (\%) } \\
2004\end{array}$ & $\begin{array}{r}\text { Populati } \\
\text { on } \\
\text { density }\end{array}$ & $\begin{array}{c}\text { Total } \\
\text { Fertility } \\
\text { Rate } \\
\text { (\%) }\end{array}$ & $\begin{array}{c}\text { Household } \\
\text { avarege- } \\
\text { person }\end{array}$ \\
\hline $\begin{array}{l}\text { Türkiye- } \\
\text { TR }\end{array}$ & $67,803,9$ & 64,9 & 14.9 & 86 & 2,53 & 4,5 \\
\hline $\begin{array}{l}\text { South } \\
\text { East } \\
\text { Anatolia- } \\
\text { TRC }\end{array}$ & $6,608,619$ & 62,69 & 21.23 & 86 & 4,57 & 6,48 \\
\hline $\begin{array}{l}\text { Şanlıurfa, } \\
\text { Diyarbakı } \\
\text { r-TRC2 }\end{array}$ & $2,806,130$ & 59,15 & 24.6 & 80 & 4,68 & 6,76 \\
\hline $\begin{array}{l}\text { Şanlıurfa- } \\
\text { TRC21 }\end{array}$ & $1,443,42$ & 58,34 & 30.9 & 75 & 4,83 & 6,87 \\
\hline $\begin{array}{l}\text { Diyarbakı } \\
\text { r-TRC22 }\end{array}$ & $1,627,08$ & 60 & 18.4 & 87 & 4,51 & 6,64 \\
\hline $\begin{array}{l}\text { Zongulda } \\
\text { k-TR811 }\end{array}$ & 615,599 & 40,66 & $-10,08$ & 186 & 1,93 & 4,23 \\
\hline $\begin{array}{l}\text { İstanbul- } \\
\text { TR100 }\end{array}$ & $10,018,73$ & 90,69 & 30,73 & 1,885 & 1,97 & 3,93 \\
\hline
\end{tabular}

Source: TUIK, DPT, Annual Statistical Reports.

\section{Table 2.: Migration Datas}

\begin{tabular}{|l|r|r|r|r|r|}
\hline \multicolumn{1}{|c|}{ Codes } & $\begin{array}{c}\text { Permenant } \\
\text { Settlement } \\
\text { population } \\
\mathbf{2 0 0 0 0}\end{array}$ & $\begin{array}{c}\text { In- } \\
\text { migration }\end{array}$ & $\begin{array}{c}\text { Out- } \\
\text { migration }\end{array}$ & $\begin{array}{c}\text { Net } \\
\text { Migration }\end{array}$ & $\begin{array}{c}\text { Growth } \\
\text { of Net } \\
\text { Migration }\end{array}$ \\
\hline Türkiye-TR & $60,752,995$ & $40,983,56$ & $40,983,56$ & 0 & 0 \\
\hline SouthEasthern-TRC & $5,687,740$ & 212,425 & $4,223,15$ & $-209,890$ & -36.23 \\
\hline $\begin{array}{l}\text { Şanlıurfa,Diyarbakır- } \\
\text { TRC2 }\end{array}$ & $2,419,448$ & 96,864 & 194,240 & $-97,376$ & -39.45 \\
\hline Şanlıurfa-TRC21 & $1,243,058$ & 38,320 & 87,632 & $-49,312$ & -38.9 \\
\hline Diyarbakır-TRC22 & $1,176,390$ & 62,996 & 111,060 & $-48,064$ & -40.04 \\
\hline Antalya-TR611 & $1,451,771$ & 171,982 & 81,525 & 90,457 & 64.31 \\
\hline Zonguldak-TR811 & 574,182 & 27,839 & 71,848 & $-44,009$ & -73.82 \\
\hline
\end{tabular}

Source: TUIK, DPT, Annual Statistical Reports. 
Regarding literacy rate it is very low particularly among women (52\%) which is far below the average of Turkey (\%80). Another striking issue is the extent of net outmigration in Sanliurfa $(-39(\%)$. Namely, 39 out of 1000 persons migrate from Sanliurfa. As it may be seen in Tablo 2, the province with the highest net outmigration is Zonguldak- 74 (\%), and Antalya ranks first in term of net inmigration. One needs to analyze the structure of the labor market of Sanliurfa to understand the reasons of outmigration in Şanlıurfa.

\subsection{Economic Structure and Labour Market}

Economic structure of Sanliurfa is mainly based on the agriculture sector. According to 2000 data, the sectoral breakdown of regions GDP is agriculture (43\%), services (40\%), industry (11\%) and construction (6\%). GDP in 2000 is 1 billion 850 Million Dollars, and income per capita is 1.300 Dollars. However referring to the labour market data, we see that employment generating capacity of agriculture sector has been declining. As it may be seen in (Table 3), in terms of TRC2 -Urfa-Diyarbakir data, employment share of agricultural has declined from $47.4 \%$ in 2004 to $26.9 \%$ in 2006 . On the other hand the share of industry in employment is increasing gradually as it increased from $12.1 \%$ in 2004 to $16.2 \%$ in 2006 .

Another striking point is that labour force participation rate has been declining in the recent years. The participation rate which was $39 \%$ in 2004 decreased to $32 \%$ as of 2006. Findings of a recent research carried out by State Planning Institute reveals that the number of people who have no hope in finding a job is highest in Şanlıurfa (105,000 people) amoung all the provinces of Turkey. On the other hand the highest number of people that leave the region for seasonal works is also very high. Declining employment opportunities in agriculture, inadequate access to education and leisure facilities and declining job opportunities in the public sector employment due to recent climate of fiscal restraint are amoung the main reasons of high rates of outmigration from Şanlıurfa. 
Menevis Uzbay PİRILİ ve R.Funda BARBAROS

Table 3: Distribution of Employment by Sector

\begin{tabular}{|c|c|c|c|c|c|c|c|c|c|c|}
\hline \multirow[t]{2}{*}{ Codes } & & \multicolumn{3}{|c|}{2004} & \multicolumn{3}{|c|}{2005} & \multicolumn{3}{|c|}{2006} \\
\hline & & Agriculture & Industry & Service & Agriculture & Industry & Service & Agriculture & Industry & Service \\
\hline \multirow[t]{2}{*}{ Türkiye-TR } & $\begin{array}{l}\text { Person } \\
\text { Thousand }\end{array}$ & 7,400 & 5,017 & 9,375 & 6,493 & 5,456 & 10,097 & 6,088 & 5,674 & 10,568 \\
\hline & $\%$ & 34,0 & 23,0 & 43,0 & 29,5 & 24,7 & 45,8 & 27,3 & 25,4 & 47,3 \\
\hline \multirow[t]{2}{*}{$\begin{array}{l}\text { Güneydoğu- } \\
\text { TRC }\end{array}$} & $\begin{array}{l}\text { Person } \\
\text { Thousand }\end{array}$ & 572 & 249 & 635 & 408 & 292 & 673 & 299 & 294 & 654 \\
\hline & $\%$ & 39,3 & 17,1 & 43,6 & 29,7 & 21,3 & 49,0 & 24,0 & 23,6 & \\
\hline \multirow{2}{*}{$\begin{array}{l}\text { Şanlıurfa- } \\
\text { Diyarbakır } \\
\text { TRC2 }\end{array}$} & $\begin{array}{l}\text { Person } \\
\text { Thousand }\end{array}$ & 275 & 70 & 234 & 210 & 76 & 264 & 136 & 82 & 287 \\
\hline & $\%$ & 47,4 & 12,1 & 40,1 & 38,1 & 13,8 & 47.9 & 26.9 & 16.2 & 56,8 \\
\hline \multirow{2}{*}{$\begin{array}{l}\text { Ağrı,Kars, lğdır } \\
\text {,Ardahan } \\
\text { TRA2 }\end{array}$} & $\begin{array}{l}\text { Person } \\
\text { Thousand }\end{array}$ & 209 & 14 & 94 & 201 & 18 & 107 & 172 & 18 & 116 \\
\hline & $\%$ & 65,9 & 4,4 & 29,7 & 61,7 & 5,5 & 32,8 & 56,0 & 5,9 & 37,8 \\
\hline \multirow[t]{2}{*}{$\begin{array}{l}\text { İstanbul } \\
\text { TR100 }\end{array}$} & $\begin{array}{l}\text { Person } \\
\text { Thousand }\end{array}$ & 26 & 1,412 & 1,880 & 23 & 1,527 & 2,005 & 19 & 1,538 & 2,119 \\
\hline & $\%$ & 0,8 & 42,6 & 56,7 & 0,6 & 42,9 & 56,4 & 0,5 & 41,8 & 57,6 \\
\hline
\end{tabular}

Source: TUIK, DPT, Annual Statistical Reports. TUIKK Genel Sanayi ve İşyerleri Sayımı, Geçici Sonuçlarına Göre İ İşyeri

Sayısı ve İstihdam, 2005. 


\subsection{Agriculture}

Table 4 shows that Sanliurfa owns rich and plentiful land resources for farming activity. $1.200 .572,5$ hectares of its 1.858 .400 -hectare-area constitute the agricultural area of the region. 836.000 hectares of this area is suitable for irrigation. Currently 313.025 hectares of agricultural area can be irrigated. 167.325 hectares of this irrigation is provided by state and 145.700 hectares is provided by the public. Agricultural area of Urfa consists 13\% of Turkey's agricultural area and it also constitutes $35 \%$ of agricultural area of southeastern region.

Table 4: Total Agriculture Arrable Land

\begin{tabular}{|l|c|c|}
\hline \multicolumn{1}{|c|}{ Regions } & Land Area -Ha & Percentage share \% \\
\hline TRC- South Easthern Anatolia & 3.453 .464 & 13 (in Turkey) \\
\hline TRC 2 Şanlı Urfa-Diyarbakır & 1.995 .235 & 58 (in TRC) \\
\hline TRC 21-Şanlı Urfa & 1.200 .572 & 35 (in TRC) \\
\hline TRC 22- Diyarbakır & 798428 & 23 (in TRC) \\
\hline
\end{tabular}

Source: Şanlı Urfa Tarım İ Müdürlüğü, Şanlı Urfa Sanayi ve Ticaret Odası, TUík

Table 5.: Agriculture Products Before/After GAP

\begin{tabular}{|l|c|}
\hline \multicolumn{2}{|c|}{ Before GAP } \\
\hline Products & Wheat, Lentil, Pistachio, Sesame, Barley \\
\hline \multicolumn{2}{|c|}{ After GAP } \\
\hline Products & Ton/year \\
\hline Wheat & 1442884 \\
\hline Barley & 762767 \\
\hline Lentil & 209314 \\
\hline Sesame & 5368 \\
\hline Cotton & 867790 \\
\hline Corn & 18300 \\
\hline Pistachio & 42097 \\
\hline Tomato & 81507 \\
\hline Aubergine & 53352 \\
\hline
\end{tabular}

Source: Şanlı Urfa Tarım II Müdürlüğü 
Şanlıurfa is one of the major producers of cotton, wheat and barley in Turkey. Other farming products produce are red lentil, pistachio, grape, sesame and various vegetables. After 1995 with the initiation of GAP, there has been a great increase in cotton production; cotton production which was 277.000 tons in 1995 increased to 708,602 tons/year in 2004. (Table 5)

In Turkey, $30 \%$ of total cotton production; $11 \%$ of total dry legumes production; $6.4 \%$ of total barley production; $4 \%$ of total wheat production is provided by Sanliurfa.

\subsection{Farming of Animals}

Sheep and goat farming is at the forefront in terms of husbandry. In spite of the fact that bovine breeding is not at expected levels, it is improving gradually. In 2006, the amount of farmed animals are as follows; sheep and goat 1.584 .495 unit/per year,; cattle breeding 144. 848 unit/per year; poultry 1.010 .097 unit/per year; bee hive 8.491 unit/per year.

As it may be seen in Table 6, almost 9,000 tons of meat were produced in the region in 2002.

Table 6: Manufacture of Meat Products (2002)

\begin{tabular}{|l|c|}
\hline \multicolumn{1}{|c|}{ Products } & Amount \\
& \\
\hline Meat (Ton) & 8.688 \\
\hline Leather (Unit) & 168.573 \\
\hline Milk (Ton) & 166.495 \\
\hline Honey (Kg) & 90.143 \\
\hline
\end{tabular}

Source: Şanlı Urfa Tarım III Müdürlüğü

Atatürk Dam and Euphrates River offer valuable potentials in terms of fisheries and fish breeding. Total 38,835-hectare of water surface comprises 1430 hectares of ponds and nearly 37,405 hectares of dam area. The potential of this area in terms of fishery products is of great importance. Implantation works carried out to protect and increase available fishery products potential in lakes, pounds and dams, and to make use of the new resources efficiently have an important impact on the development of fishery in the province. Total production of fishery products is 405 tons as of 2001 in the region, and 30 tons of this figure was provided by aquaculture. As a result of the studies to be carried out in the region it is expected that the production will reach 3700 tons through hunting and 2000 tons through aquaculture. The available production which is 405 tons/year will reach 5700 tons/year. 
According to a study entitled "Regional Development Policies in Turkey" carried out by TUSIAD and DPT (2005), Urfa-Diyarbakır Region, among the 26 NUTS 2 Regions;

- Ranks first in field crops (1.6)

- Ranks last in fruit and vegetable (0.3)

- Ranks second in sheep and goat farming after TRB2 (Bitlis, Hakkari, Van, Muş) (1.77)

- Also ranks among the top provinces in meat production (1.78)

A crucial problem in the region is the salting of land due to over irrigation which is also called high ground water. 1.512 hectares of the total land area has already been suffering from this problem. Drainage works and reconstruction works are underway inorder to tackle this issue.

To sum up, inspite of the many problems, agriculture still plays an important role in shaping the rural landscape and the regions economy therefore it remains a wellspring of regional support for development. However this would make sense if agriculture is conceived more as a part of a regional restructuring process towards multisectoral approaches, than as a traditional sector producing commodities.

\subsection{Industry}

While the share of employment in agriculture has been declining, the employment share of industry has been increasing and reached $16.2 \%$ in 2006 . The number of the firms employing two or more workers in manufacturing sector increased rapidly in recent years and this number is 2.933 as of 2002. With regards the industry sector as a whole (manufacturing, electricity, gas and water and construction) the number of companies and the number of workers are 3.138 and 16.392 consecutively.

In 1992, contractions works for First Organized Industrial Zone was launched and its was completed in 2000 except waste treatment facilities. 295 industry parcels were allocated to 148 entrepreneurs. As of today, 135 factories are operating, 23 factories are under construction, and 11 factories are in the phase of project. When all of these facilities are completed in 1. Organized Industrial Zone where 4.500 people are employed, in total 8.000 people will be employed. Since the First Organized Industrial Zone could not meet the demands of high number of entrepreneurs, construction works for the Second Organized Industrial Zone was launched. The total area of 2. Organized Industrial Zone which was included in 1997 investment Programme is 1186 hectares. 


\section{INDUSTRY AND SERVICES SECTORS IN ŞANLIURFA: KEY SECTOR ANALYSIS}

\subsection{Clusters And Key Sector Analysis}

The idea that national economic success depends, in part at least, on the development of localised concentrations of industrial specialisation can be traced back more than one hundred years to Alfred Marshall (Marshal, 1949). $\mathrm{He}$ argued that Britain's economic growth and leadership during the 19th century was founded on the development of several examples of localised industries. Examples include cotton textiles in Lancashire, the potteries district around Stoke, furniture around High Wycombe, and so on.

A century later, economists have rediscovered Marshall's work on industrial localisation. Their argument is that regional economic agglomeration and specialisation can maximise the potential offered by technological, market and other externalities that underpin increasing returns hence the more geographically localised is an industry within a given nation, the more internationally competitive that particular industry is likely to be (Porter, 1990, 1998; Krugman, 1991, 1993; Antonelli 2003).

Porter's identification of these contemporary local economic agglomerations has been especially influential, and his term 'industrial cluster' has become the standard concept in this field. Porter's concept of 'clusters'(Porter, 1990), originated in his work on international competitiveness argues that the leading exporting firms in a range of different countries are not isolated success stories but belong to successful groups of rivals within related industries. These groups are termed clusters, which refers to industries related by horizontal and vertical links of various kinds.

The definition of Clusters according to M. Porter is as follows:

"Clusters are Geographic concentrations of interconnected companies, specialised suppliers, service providers, firms in related industries, and associated institutions (for example, universities, standards agencies, and trade associations) in particular fields that compete but also co-operate" (Porter,1998.op. cit. page 197)

Accordingly clusters lead to higher growth in three main ways.

-First, they raise productivity by allowing access to specialised inputs and employees, by enhancing access to information, institutions and public goods and by facilitating complementarities.

-Second, they increase firms' capacity for innovation by diffusing technological knowledge and innovations more rapidly. 
-Third, clusters stimulate higher rates of new business formation, as employees become entrepreneurs in spin-off ventures. Over the past few years, the cluster approach has found an audience amongst policy-makers at al levels. The idea is that governments and local authorities can help to provide the business and institutional environment necessary to cluster success. Identifying high point sectors and industries at the regional level is a prerequisite for cluster study.

Over the past few years the cluster approach has found an audience amongst policy-makers at al levels. The idea is that governments and local authorities can help to provide the business and institutional environment necessary to cluster success. In Turkey in the framework of the nations accession to EU, there has been a number of case studies realized which aim at identifying high point industries at NUTS 1 and NUTS 2 levels Some of those studies have been analyzed by Akgüngör, Kumral and Lenger (2003), Kumral and Deger (2003), Akgüngör (2003), Kumral and Değer (2004), TUSIAD and DPT (2005) and DPT (2006). These studies have had significant contributions to Turkey's regional development issues both at theoretical and political levels.

\subsection{High Point Industries (Key Sectors) Analysis in Şanlı Urfa}

The scope of our study covers the entire industry and services sectors in the Province of Şanlıurfa. It aims at investigating each and every regional sector to determine whether and to what extent they may form high points in the province. Hence the findings of this study is expected to contribute to the previously realized studies

\section{Method}

The fundamental quantitative measure of firm activity we use is that of employment. Four digit NACE 1.1 codes, regarding employment data and belonging to the years of 2002 is utilized inorder to obtain a relative measure of employment density known as the location quotient (LQ). Hence LQ analysis is the main technique used to determine the high point industries in the region. $L Q$ is defined as follows:

$\mathrm{LQ}=(\mathrm{Eij} / \mathrm{Ej}) /(E i n / E n)$ or $\mathrm{LQ}=(\mathrm{Eij} / \mathrm{Ein}) /(E \mathrm{Ej} / E n)$ where

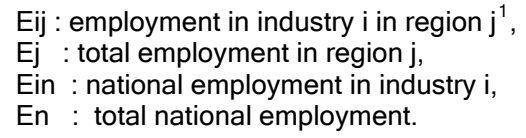

The $L Q$ values will measure the share of a given industry's employment in Şanlıurfa relative to the region's share of total national employment. An LQ greater than 1.5 indicates that there is an above average proportion of

\footnotetext{
${ }^{1}$ Region j would always be taken as Sanlıurfa in this analysis.
} 
employment in a given industry in a given region. Those sectors with an $L Q$ value greater than 1.5 will be identified as key industries (high point sectors).

An LQ greater than 1.5 indicates that there is an above average proportion of employment in a given industry in a given region. Conversely for an LQ of less than 1.5. Those sectors with an LQ value greater than 1.5 will be identified as key sectors (high point sectors) in Şanlıurfa. Sectors which have been covered in the study and their relevant codes are as follows:

Industry Sectors: Manufacturing Industry (D); Electricity, Gas and Water (E); and Construction $(F)$. Service Sectors : Wholesale and Retail trade (G) ; Hotels and restaurants $(\mathrm{H})$, Transportation, Storage and Communication (I), Activities of Financial Intermediary Institutions $(\mathrm{J})$, activities of Real estate, Renting and Business (K), Education (M), Healthy Affairs and Social Services (N), Other Social and Private Activities (I)

The sector level data that has been used comes from two sources: Firstly from the "Manufacturing Industry Surveys" and 1992 and 2002 "General Census Of Industry And Business Establishments" provided by the State Statistics Institute of Turkey. The second data source will be Chambers of Industry and Trade of Şanlı Urfa. The data is based on four digit Nomenclature of Economic Activities (NACE) .

\subsection{Empirical Results ${ }^{2}$}

\subsubsection{High Point Sectors In Industry}

As seen in Table 7, 19 High Point Industries have been identified in ŞanlıUrfa Region's Manufacturing Industry. The main high point sectors identified are basically in food products and in the textile sector.

Food Industry the high point sector with the highest $L Q$ value is Manufacture of Diary Products (code. 1551; LQ = 21.26). Other high point sectors with high LQ values are Manufacture of Bakery Products (1581) and Manufacture of Vegetable and animal oil and fats (1541).

Textile Industry, Only one high point sector, preparation and spinning of cotton type fibers (1711) has been identified. As indicated above Urfa is the major cotton producer in Turkey. 1711 sector constitutes the first stage in textile production and most of the companies amoung the 57 sited in the table are mainly cotton fibers spinning factories. The share of identified high point food industries and textile industry within the total manufacturing employment is

\footnotetext{
2 The detailed tables showing all the LQ values measured can be provided by the authers upon request.
} 
(54.1\%). The share of these within the total number of establishments in manufacturing industry accounts to $(35.2 \%)$.

Other high points industries identified are those sectors that provide input to the fast developing construction sector which accounts for $11 \%$ of the GDP in Şanlı Urfa. These high point sectors are manufacture of builders carpentry (2640), manufacture of bricks and tiles and construction products in clay (2661) and manufacture of plaster products for construction (2662).

Treatment and coating of metals (2851) is another key industry with a high LQ (4.2) value identified in Urfa. Urfa with its very rich cultural and religious heritage and historical places is an important tourist site in the SouthEastern Anatolia. The high $L Q$ values of 2851 sector is due to the very lively souvenier products trade in the city. A majority of the souvenirs are made form various metals and especially form copper.

Manufacture of pumps and compressors (2912) and manufacture of other agricultural machinery are two other key sectors identified. The agriculture based structure of the province gives rise to development of these industries in the city.

In general the share of the 19 high point manufacturing industries in the total manufacturing sector's employment of Şanlı Urfa is as high as (74\%). On the other hand share of establishments of these sectors in the total number of establishments in the manufacturing industry is (67.2\%). In the industry sector apart from the manufacturing industry four sub sectors are identified as key industries (high point sectors) in the region. Amoung these;

Construction of water projects (4524) is identified as having a very high LQ value (16.22). The significance of this industry is due to the South Anatolian Project - GAP and the Atatürk dam constructed in the region.

General Construction of Building and Civil Engineering Works (4521) is also another high point sector identified. This is due to the fact that Şanlı Urfa has been receiving inward migration from the various provinces in the South Anatolian Region which gives rise to the flourishing of the constructions sector especially in the central province. 
Menevis Uzbay PİRILİ ve R.Funda BARBAROS

Table 7: Key Sectors in Şanlıurfa Industry Sector

MANUFACTURING INDUSTRY (D)

(people)

MANUFACTURE OF FOOD PRODUCTS, BEVERAGES AND TOBACCO

\section{Manufacture of crude oils and fats}

- Operation of dairies and cheese making

-Manufacture of ice cream

- Manufacture of grain mill products

-Manufacture of bread; manufacture of fresh pastry goods and cakes

MANUFACTURE OF TEXTILES AND TEXTILE PRODUCTS

- Preparation and spinning of cotton-type fibres

MANUFACTURE OF WOOD AND WOOD PRODUCTS

- Manufacture of builders' carpentry and joinery

$\begin{array}{rcrr}1541 & 2,615745 & 9 & 1727 \\ 1551 & 21,26409 & 6 & 19 \\ 1552 & 2,448733 & 9 & 324 \\ 1561 & 2,556871 & 142 & 3315 \\ 1581 & 6,210733 & 803 & \\ & & 57 & 966 \\ 1711 & 2,005054 & & 766 \\ & & 366 & \end{array}$


Table 7: Key Sectors in Şanlıurfa Industry Sector (Continued) MANUFACTURING INDUSTRY (D)

Codes LQ

Number of Firms Employment

(people)

MANUFACTURE OF OTHER NON-METALLIC MINERAL PRODUCTS

- Manufacture of bricks, tiles and construction products, in baked

clay

- Manufacture of concrete products for construction purposes

$2640 \quad 1,957132$

$2661 \quad 2,268367$

- Manufacture of plaster products for construction purposes

$2662 \quad 2,436588$

- Manufacture of ready-mixed concrete

26631,857636

MANUFACTURE OF FABRICATED METAL PRODUCTS, EXCEPT MACHINERY AND EQUIPMENT

- Manufacture of builders' carpentry and joinery of metal $\quad 2812 \quad 2,452018$

- Treatment and coating of metals

- Manufacture of pumps and compressors

$2912 \quad 2,556782$

- Manufacture of agricultural tractors

$\begin{array}{ll}2912 & 2,556782 \\ 2931 & 1,49153\end{array}$

- Manufacture of non-electric domestic appliances

$2972 \quad 1,900737$

MANUFACTURE OF ELECTRICAL MACHINERY AND APPARATUS

- Manufacture of electric motors, generators and transformers

$3110 \quad 1,946323$

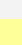

MANUFACTURE OF JEWELLERY AND RELATED ARTICLES

KEY MANUFACTURING SECTORS (D) TOTAL

36221,515522

ELECTRICITY, GAS, WATER (E) and CONSTRUCTION (F)

- Collection, purification and distribution of water

- Test drilling and boring

- General construction of buildings and civil engineering Works

- Construction of water projects

- Other building installation

$$
\begin{aligned}
& \text { Key sectors in } E \text { ve } F \quad \text { Total } \\
& \text { Key Sectors in D, E ve } F \text { Total }
\end{aligned}
$$




\subsubsection{High Point Sectors In Services}

We identified two main services sectors that have $L Q$ values greater than 1.5. These are

$\begin{array}{llc}\text { Code } & \text { SECTORS } & \text { LQ value } \\ \text { G } & \text { Wholesale and Retail Trade } & 1.87 \\ \text { I } & \text { Communicaiton and Transportation } & 1.85\end{array}$

Most of the sub sectors within these two sectors have $L Q$ values greater than one. Those subsectors that have LQ values greater than two are as follows: ${ }^{3}$

Services Sectors Having Lq Value Greater Than Two:

- Sale, maintenance and repair of motorcycles and related parts and accessories 5040 ; LQ Valuer: 2.99

- Agents involved in the sale of furniture, household goods, hardware and ironmongery 5115; LQ Value : 5.02

- Agents involved in the sale of food, beverages and tobacco 5117; LQ value: 4.02

- Wholesale of grain, seeds and animal feeds 5121; LQ value: 2.69

- Wholesale of dairy produce, eggs and edible oils and fats 5133; LQ value: 3.84

- Non-specialized wholesale of food, beverages and tobacco 5139; LQ Value: 4.04

- Retail sale of meat and meat products 5222; LQ Value: 3.19

- Retail sale of textiles 5241; LQ value: 2.17

- Freight transport by road 6024; LQ Value: 4.04

Wholesale and Retail Trade, is a sector that has been growing in the recent years both in terms of its share in GDP of the region and also in employment. Its share has ncreased from $40 \%$ in $200452 \%$ in 2006 . On the other hand the key sectors identified in our analysis are those services sectors that have a close input-out relationship with the agriculture sector such as wholesale of seeds, dairy products, retail sale of meat and meat products and textiles.

Freight Transport by Road has been found to have a very high $L Q$ value (4.08). The main reason of this high share is dut o the fact that Şanlıurfa is situated on the main road between Mersin Port and Habur Customs Gate to Iraque. In the recent years military equipment and food stuff arriving at Mersin Port are transported by road to Iraque through the Habur gate. On the other hand after the competition of reconstruction Works at Akçakale Customs Gate which is on

\footnotetext{
${ }^{3}$ Relevant tables covering the LQ values in Services sector in Urfa will be provided by the authers upon request.
} 
the border between Şanlıurfa and Syria , freight Transport by road sector is expected to flourish even further.

\section{ORGANIC AGRICULTURE AND SANLIURFA}

It is estimated that organic agriculture is carried out in more than 24 million hectares all over the world. The biggest parts of this area is in Australia (nearly 10 million hectares), Argentina (nearly 3 million hectares) and Italy (nearly 1.2 million hectares). While Australia has $42 \%$ of the organic agriculture area in the world, North America follows it altough Latin America and Western Europe ranked first in the world for a long time in terms of organic food and beverage market. The sale of organic products reached 10.5 billion Dollars by increasing $8 \%$ in 2002. In 2002, Germany, the biggest market in Europe, spent 3.06 billion Dollar for organic agriculture; England, the third biggest market in the world spent 1.5 billion Dollars; and the markets of Italy and France spent 1.3 billion Dollar. North America organic product market is the fastest growing one in the world.

The sale of organic food and beverages reached 11.75 billion Dollars with an increase of $12 \%$ in 2002. Although the second largest organic agriculture area is in Latin America, it has a very small market in terms of marketing of these products (Turkishtime, 2004).

According to the estimations, the world's trade volume regarding organic products will increase from 11 billion Dollars to 100 billion Dollars within the next 10 years. Actors both public and private all around the world and especially in European countries, have realized the huge potentials this sector may offer and hence organic agriculture promises huge development prospects in the future

Ecologic Agriculture Organization Association (ETO) was established in 1992 in order to materialize a sound ecologic (organic) agriculture movement in Turkey. "II. Conference on Ecologic Agriculture in Mediterranean Countries" was held in Izmir by ETO within the same year. With the initiation of a new perspective on ecological agriculture in Turkey, Izmir city has become the leading center of this movement. Currently 12.275 organic producers produce 168.306 tons of 92 different types of ecologic products cultivating on a 46.523 hectare land area. Although there is lack of accurate data regarding net contribution of ecologic agriculture sector to the economy via exports which is due to various problems in customs legislation, it is estimated that this figure is nearly 150 million dollars. 


\section{Map 2: Ecological Zones in Turkey by FAO}

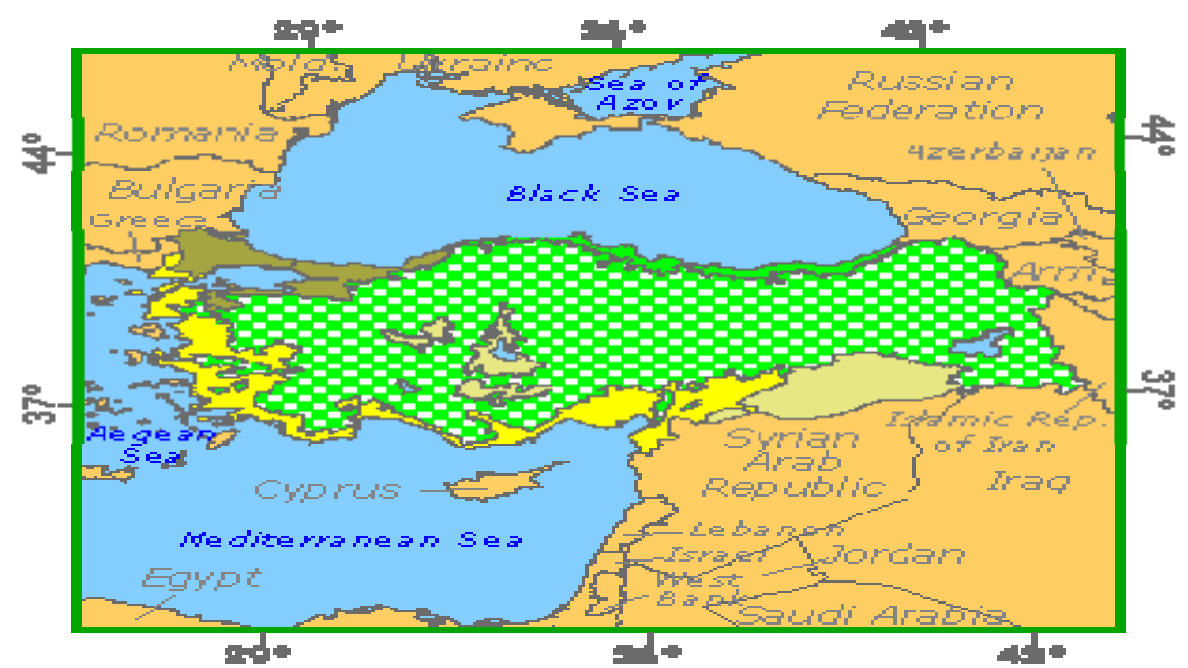

\subsection{Organic Agriculture in Sanliiurfa ${ }^{4}$}

After 1995 with the introduction of GAP irrigated farming (as contrary to dry farming) became widespread in Sanliurfa. Majority of the farmers started to plant cotton, which had a ready market outside hence a spectacular increases in cotton production. However as a result of excessive irrigation, serious problems emerged such as salinity, drought and pollution of the soil through pesticides

The eligible areas for organic agriculture in Sanliurfa province are in Siverek, Karacadağ, Bozova, Birecik, Akziyaret, Viranşehir, Hilvan geographic borders. On the other hand after the removal of land mines, a very large area suitable for organic agriculture will be obtained.

\subsection{Organic Agriculture Products in Sanliurfa}

Medical and Aromatic Plants: Anasone, Fenugreek, Cummin, Coriander, Mint (Mentha Piperita L. or the plant named as English mint has pharmacologic peculiarities and Turkey exports this product.), Thyme, Crocus (The market

\footnotetext{
${ }^{4}$ GAP-GIDEM Entrepreneur Support Centers have been carrying out cluster analysis in the South-eastern Anatolia Region within the framework of EU-GAP Regional Development Programme 2002-2007 and in collaboration with UNDP. The below information is based on the findings of the Report on Organic Agriculture Clusters in Şanlıurfa (Bulu and Eraslan 2004)
} 
value of per kilo is almost 2000 USA Dollars. Its added value is quite high and it is in line with genetic material of Sanliurfa. It can only grows around Safranbolu in Turkey. The pilot production of this plant was carried out by GAP(Agricultural Development Önder Çiftçi Consultancy Association.)

Nuts: Pistage, Almond, Industrial Plants,

Fruit trees. Fig, Grapes, Plum, Olive.

Vegetables. All kinds of vegetables can grow. The vehicles having "intercooling" feature is necessary in order to transport the vegetables.

Cereals and Grain: Barley, Wheat, Lentil, Chickpea.

Reverse/Crying Tulip (The liquid that comes out from the plant represents the tears of Virgin Mary.) is also worth mentioning amoung natural flora.

\subsection{Organic Husbandary}

As it may be known, crop shift is necessary for organic agriculture. Within this context, fodder crops are advised as alternative products. "Fodder cost" in husbandry constitutes $70 \%$ of the total cost. Hence the product obtained from fodder crops during organic agriculture application will be used in organic fodder production, and in line with this practice, organic husbandry will improve in the region.

On the other hand the sub sectors of poultry and apiculture could not improve since the climate and geographic conditions of the region impede those. Only in Karacadağ area, there is an environment known as suitable for apiculture, and small scale apiculture is carried out there.

In Sanliurfa Province, there are a limited number of producers producing via utilizing organic agriculture method. The products are as follows: medical and aromatic plants such as mulberry, pomegranate, tomato, grapes, wheat, soy bean, nigella, and pistachio and spices. Ceylanpınar is pretty suitable for organic milk.

\subsection{Actors in Sanliurfa Organic Agriculture Group}

\section{A) Producers}

Companies of Roza Ecologic Agricultural Nutrition Products Corp. and Selim Uludağ Organic Agriculture Corp., and farmers; İbrahim Ethem Polat and Mehmet Emin Yıldırım carry out organic agriculture. General Directorate of Ceylanpınar Agriculture Enterprise produces organic cotton and peanut as a trial. Moreover Koç-Ata-Sancak Nutrition and Agricultural Products Corp. operating as one of the most modern agriculture enterprises in the region has the potential yet it has no organic agriculture activity. 
B) Non Governmental Organisations:

- GAP Agricultural Development Önder Çiftçi Consultancy Association

- GAP Sustainable Agricultural Development Association

- AGRO-GAP Önder Çiftçi Consultancy Association

C) DATA generating Institutions

- Harran University, Faculty of Agriculture

- Siverek Vocational School of Higher Education

D) State and Public Institutions

- GAP - GIDEM

- Provincial Directorate of Agriculture

- Social Security Authority (SSK)

- Social Security Organization for Artisans and Self Employed (Bagkur)

E) Other Institutions

- Şanlıurfa Trade and Industry Chamber (ŞUTSO)

- Şanlıurfa Young Businessman Association (ŞUGIAD)

F) Customers

- Major players, namely producers are limited

- The relations with certification organizations are weak

- Financing demand: Banking sector is advanced in the region yet new financing opportunities may be provided

- There is no adequate network with NGOs but there are relations between them

- There are few customers and most of them are domestic. This field should be certainly improved.

- The relations with data generating institutions are very weak

- There is adequate infrastructure that will meet energy demand

- The relation with GIDEM is developed

- There is quite limited relation with TÜBITAK

According to the level analysis in grouping, the density of the other players; particularly public institutions and data generating institutions is relatively limited. It is of great importance that these players have active roles in terms of sound development of grouping in long run. For instance there is only one network with TÜBITAK. 


\section{Map 3: Sanli Urfa Cluster Map}

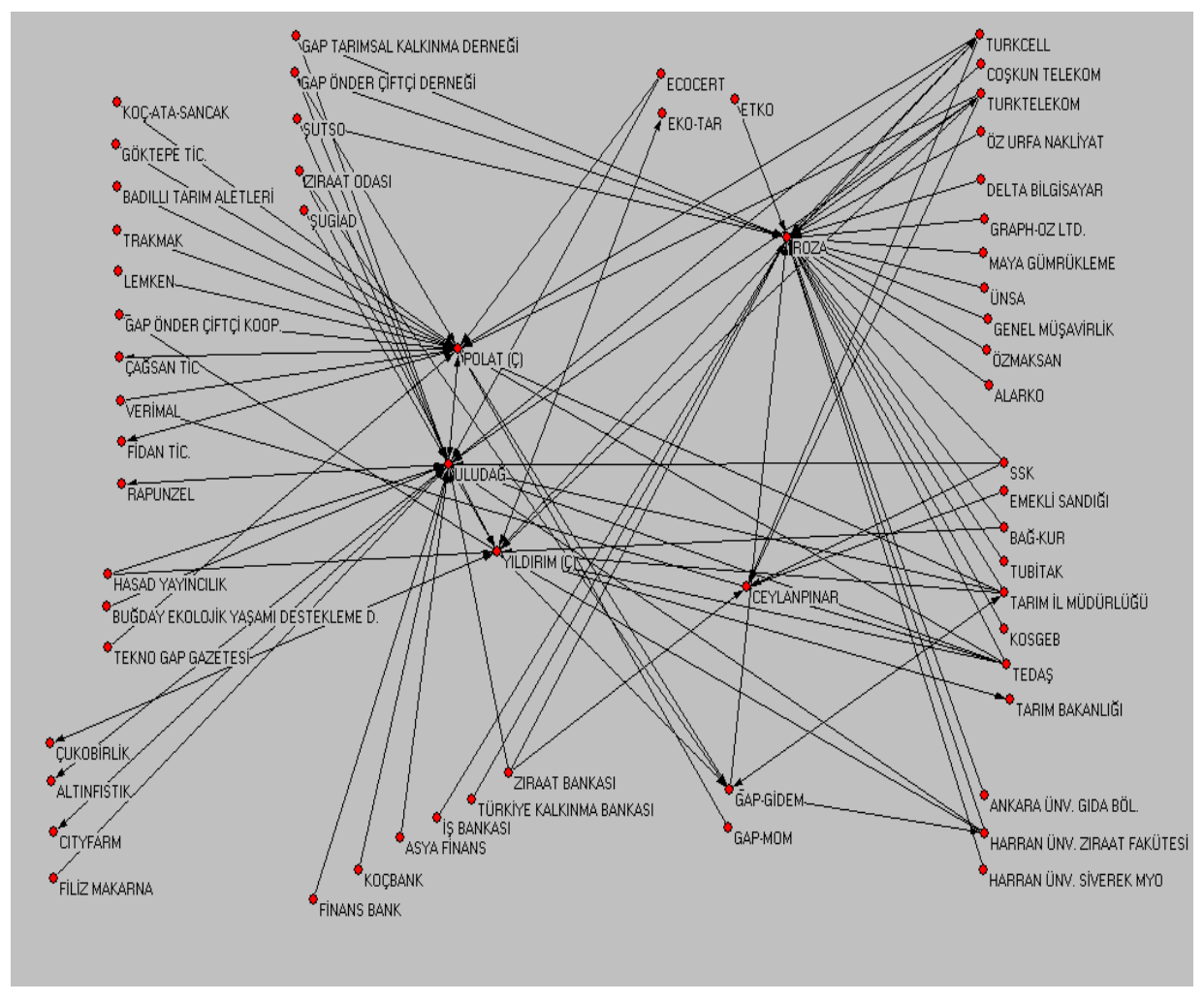

Source: Bulu and Eraslan, 2004

Moreover the density figure is 0.0376 . The value of density is very close to zero. This demonstrates us that there is a limited relation between players. However, in spite of the fact that this situation indicates a weak grouping, it is seen that there is a serious potential to be acquired by enhancing the relations between players.

\section{FINDINGS AND CONCLUDING REMARKS}

The challenges facing Şanlıurfa regarding its economic development is not unique, they are the same challenges found in rural areas all around the world. Although agriculture is still the most important economic sector in Şanlıurfa (with $42 \%$ of the population living in rural areas and the agriculture's share in regions GDP amounts to $43 \%$ ), it is producing fewer and fewer jobs. This is evident from the fact that the employment share of agriculture has fallen from nearly $48 \%$ in 2004 to $26 \%$ in 2006 in TRC2 region. The region suffers from the 
highest outmigration rates all over Turkey. Declining employment opportunities in agriculture, inadequate access to education and leisure facilities and declining job opportunities in the public sector employment due to recent climate of fiscal restraint are amoung the main reasons of high rates of outmigration.

As we emphasized in the introduction, new regional development approaches and policies are responding these challenges in many different ways; and successful policies appear to have some common characterstics. First, regional policy in rural areas shifts from a focus on individual sectors (such as farm policy) to one based on territories or regions which involves coordination of policies at the local level. Second the coordination of policies at the regional level means establishing network relations amoung various public departments and agencies, knowledge producing institutes as well as private and non profit sectors. (M.Pezzini, 2001). Third, regarding the identification of the sectors that have high growth potentials in the region and also the relevant policies to be implemented, "cluster" approaches have proved to be successful.

One important feature of Sanlıurfa is that due to its agricultural basis, rich land endowment, suitable climate and clean and arable land the region has high potentials for the improvement of organic agriculture sector. As a matter of fact local public departments and agencies consider the improvement and hence support of organic agriculture to enhance the region's economy. (M. Sayın, 2000). The organic cluster map study carrried out by GAP- GiDEM- Eastern Anatolian Project Entrepreneur Support Centers, reveals that there is a strong potential for the improvement of organic agriculture, however the network relations between the possible actors of an organic cluster are still weak.

Based on this background, this paper tried to find out the development potentials of an agro-industry cluster based on organic agricultural commodities in Şanlıurfa. The findings of the study based on LQ analysis and regarding the identification of high point industries (key sectors) in the industry and services sectors of Şanlıurfa, reveal that there is a strong potential for the improvement of an industrial structure based on organic agricultural products.

Our findings reveal that the majority of the key sectors of industry in Şanlıurfa are concentrated in either manufacturing of food products or preparation of textile fibres, industries that have their basic inputs obtained from the agriculture. The following list shows the key industries in Şanlıurfa revealing high $L Q$ values 


\section{Key Industries}

Manufacture of crude oils and fats

Manufacture of diary

products

Manufacture of Grain Mill

products

Manufacture of bread,

Pastery and bread

Preperation and Spinning

of Cotton type fibres

\section{$\mathrm{LQ}$ values}

Basic Inputs from

Agriculture

Sesame, corn and cotton

Milk

Wheat

Wheat

Cotton

On the other hand the findings also support the fact that the majority of the key sectors identified in the services sector are involved in wholesale and retail trade of food and textile industry products. Services sectors with $L Q$ values greater than 2 are:

- Agents involved in the sale of food, beverages and tobacco (code: 5117)

- Wholesale of grain, seeds and animal feeds (Code:5121)

- Wholesale of dairy produce, eggs and edible oils and fats (code: 5133)

- Non-specialized wholesale of food, beverages and tobacco code: 5139)

- Retail sale of meat and meat products (code: 5222)

- Retail sale of textiles (code:5242)

Clusters include spillovers of knowledge and enhance collective learning hence they play a crucial role in promoting innovation and entrepreneurial dynamics. Clusters are important because they allow companies to be more productive and innovative than they could be in isolation. The major actors of clusters are buyers and sellers interconnected to each other in a value added chain with forward and backward linkages. The key sectors identified in the industry and services sectors of Şanlıurfa demonstrate that such a value added chain of buyer - seller relations exists between these key industries and the conventional agricultural product sectors.

Past development policies tended to focus on rural areas as one uniform block treating them as homogenous with similar problem and opportunities and the policy design and implementation were basically based on subsidizing one sector such as the farming sector. Such an approach no longer reflects the present development opportunities for rural regions. Because each rural region have certain characteristics and resources - as geographic location, topography and climate, natural resource endowments, industrial heritage and endowments of human, physical and social capital - that shape their development trajectory and potential (M. Pezzini, 2001). Together with the new impetus in regional development policy there is a shift from an approach based on subsidizing 
sectors to one based on strategic investments and hence identification of possible development strategies per type of region.

In the light of the analysis carried out in this study and also of the new approaches in regional development policy, this paper lends support to the following three issues for Şanlıurfa Region:

First, agriculture still plays an important role in shaping the economy of Şanlıurfa and it remains as a wellspring of support for development. However this would make sense if agriculture is conceived more as part of a restructuring process towards a multisectoral approach than as a traditional sector being subsidized.

Second, bearing in mind that the local public departments and agencies in Şanlıurfa give priority to the development of organic agriculture sector and cluster formation in shaping regions's development, organic agriculture cluster will constitute one component of such a multisectoral development strategy.

Third, the findings of this paper's reveal that there is great scope for the development of agro-industies cluster based on organic agriculture commodities, hence investments and support policies for the formation of an agro-industry cluster may constitute another component of such a multisectoral development strategy for Şanlıurfa

\section{References}

ANTONELLI,C. (2003) "Knowledge Complementary and Fungebility: Implications for Regional Dtrategy", Regional Studies, Vol.37. 6\&7, August/October, pp.595-606.

AKGÜNGÖR, S,, KUMRAL, N., and LENGER , A. (2003) "National Industry Clusters and Regional Specialization in Turkey", European Planning Studies Vol.11, No 6, September, pp.647-668.

AKGÜNGÖR, S. (2003) "Exploring Regional Specialization in Turkey's Manufacturing Industry", Reinventing Regions in the Global Economy, Paper Prepared for Presentation at the Regional Studies Association International Conference, 12th-15th April, Pisa, Italy.

BULU, C and ERASLAN . (2004), Şanlı Urfa Organik Tarım Kümelenme Analizi Raporu, GAP-GIDEM, Şanlı Urfa

DPT - Devlet Planlama Teşkilatı Müsteşarlığı (2006), İllerde Öne Çıkan Sanayi Sektörleri, Bölgesel Gelişme ve Yapısal Uyum Genel. Müdürlüğü, Ánkara 
DTI- Department of Trade and Industry (2001), Bussiness Clusters in the UK, Volume 3

DTI- Department of Trade and Industry (2001), UK Clusters: Performances, Policies, Emergent Issues, No.3

GAP IDARESi (2003), Şanlıurfa Ili Ekosistemine Uygun Tarımsal Ürünler Raporu, Ankara.

GAP TÜRKIYE: http://www.gapturkiye.gen.tr/il/sanliurfa.html

Gap'ta Organik Tarım, (2003) Şanlıurfa, Gap Gidem Yayınları.http://www.ankara-tarim.gov.tr/diger/organik/organik.htm

KRUGMAN, P. (1991), "Increasing Returns and Economic Geography", Journal of Political Economy, Vol: 99, pp. 484-99.

KRUGMAN, P. (1998), "What is new about The New economic Geography?", Oxford Rewiev, 14,2

KUMRAL, N., and DEĞER, Ç. (2003), "An Industrial Cluster Study: As a Basis for the Aegean Region's Development Policy", A Paper for "Reinventing Regions in the Global Economy" Regional Studies Association, 12th-15th April , Pisa Congress Center, Pisa, Italy.

PEZZiNi, M. (2001), "Rural Policy Lessons from OECD Countries" International regional Science Review, Vol.24, No. 1, pp. 134-145.

PORTER, M.E. (1990), The Competitive Advantage of Nations, London: Macmillan.

PORTER, Michael E. (1998), On Competition, A Harvard Business Review Book.

SAYIN, M. (2006), "Yerel Ekonomik Kalkınma İçin Model Önerisi", Bölgesel Klakınma ve Yönetişim Sempozyumu, ODTU.

ŞENGÜL, A ve ERSOY, (2004), Şanlı Urfa Kentinde Yoksulluk, ODTU

Şanlıurfa Genç İ̧̧adamları Derneği (ŞUGIAD), http://www.sugiad.org.tr

Şanlıurfa Ticaret ve Sanayi Odası (ŞUTSO) Yayınları, TŞOF Plaka Matbaacııık A.Ş., Ankara. http://www.sutso.org.tr

Şanlıurfa Valiliği: http://www.sanliurfa.gov.tr/ilceler/ceylanpinar/ 
TUSIAD ve DPT (2005), "Türkiye'de Bölgesel Gelişme Politikaları Sektör-Bölge Yığınlaşma Politikaları", TÜSIAD Büyüme Stratejileri Dizisi, No:4 Eylül, Yayın No. TUSIAD-T/ 2005-09/408.

Turkishtime, Orada bir Pazar var Uzakta, Türkiye İhracatçılar Meclisi Yayın Organı, 15 Nisan 2004. http://www.turkishtime.org/27/98 tr.asp

Türkiye'de Organik Tarımın Geliştirilmesi ve Yasal Düzenlemelerin Güncelleştirilmesi Çalıştayı, 21-22 Ocak 2004, Ankara 